\title{
O ENSINO REMOTO NA ÁREA DA SAÚDE, COM ENFOQUE NA EDUCAÇÃO ODONTOLÓGICA DURANTE DA PANDEMIA DO CORONAVÍRUS.
}

Semana Online Científica de Educação, 1a edição, de 25/10/2021 a 27/10/2021

ISBN dos Anais: 978-65-81152-18-5

SILVEIRA; JOSIMAR SANTORIO DA ${ }^{1}$

\section{RESUMO}

Introdução: De acordo com as orientações da Organização Mundial da Saúde frente à pandemia COVID-19, nos períodos de contágio mais intenso, abordar uma notícia cepa de coronavírus, denominadas de SARSCoV-2. Exatamente em março, a circunstância já era considerada como uma pandemia. No Brasil, de tal modo como no resto do mundo, a pandemia acarretou numerosos problemas políticos, igualitários e educacionais. Nesse argumento, a educação remota acertou a ser seguido no ensino superior carecido ao panorama antagônico às apresentações presenciais, determinado pelo distanciamento social como atitude de conter a expansão da doença. Objetivo: O contexto deste trabalho foi realizar uma revisão bibliográfica narrativa sobre o uso de instrumentos digitais, na metodologia de ensino da Odontologia, no contexto atual da pandemia de Covid-19. Métodos: Constituíram de buscas nos sites oficiais do governo e nas plataformas: como (LILACS), Biblioteca Virtual em Saúde (BVS), Scientific Eletrônic Library Online (SCIELO) e National Library of Medicine (PUBMED). Prevalecer-se os Descritores em Ciências da Saúde: Ensino em Odontologia, metodologia educacional, Covid-19, educação à distância. Resultados: Posteriormente as pesquisas, pode-se concluir que a pandemia de coronavírus impactou o ensino superior, com abordagem no curso de Odontologia, especialmente por dispor de ampla parte da sua carga horária prática presencial. A hibridização do sistema presencial e remoto se proporciona como um esperançoso modelo de ensino, com a finalidade de otimização da didática presencial, por meio de agrupamentos e discussões de forma remota. Conclusão: A ferramenta do ensino remoto de aulas online tornou-se um aliado da educação, de forma particular, perante de impedimentos, e assegura manter sua aplicabilidade, ainda pós-pandemia, consecutivamente regularizado em seu aperfeiçoamento e em sua natureza intrinsecamente retornada para consentir com coerência as distantes características e necessidades que exigem a metodologia de ensino-aprendizagem.

PALAVRAS-ChAVE: Educacao a distancia, ensino em Odontologia, metodologia educacional, covid 19 